\title{
Plasma levels, protein binding, and elimination data of lidocaine and active metabolites in cardiac patients of various ages
}

\begin{abstract}
The serum and urine levels of lidocaine and two active dealkylated metabolites, monoethylglycinexylidide (MEGX) and glycinexylidide (GX), were determined by HPLC in 33 cardiac patients receiving lidocaine for more than I day. Clinical assessment of nervous system toxicity was carried out at the time of blood drawing. The ratios in serum of MEGX to lidocaine and of $G X$ to lidocaine were $0.36 \pm 0.26$ (mean $\pm S D$ ) and $0.11 \pm 0.11$. Lidocaine and MEGX binding to serum proteins from seven patients 2 days after their myocardial infarctions were $55.4 \pm 5.9 \%$ and $14.3 \pm 3.0 \%$. After correction for this difference in protein binding, the MEGX/lidocaine ratio in serum water was $0.68 \pm 0.49$. MEGX levels in serum water were $80 \%$ or more of the lidocaine levels in 11 of the 33 patients. GX binding was $5 \pm 4 \%$. Even after correction for protein-binding differences, $G X$ levels in serum water were low compared to lidocaine levels. The steady-state serum GX concentration normalized for lidocaine infusion rate declined with age. Of 27 patients without toxicity, six had serum lidocaine levels above 8 $\mu \mathrm{g} / \mathrm{ml}$. Five of six patients with toxicity had levels less than $8 \mu \mathrm{g} / \mathrm{ml}$. The renal clearance of lidocaine, MEGX, and GX was less than creatinine clearance in most patients. We conclude that MEGX, but not GX, contributes to the pharmacologic activity of lidocaine therapy in a substantial fraction of patients. We also suggest that the concept of a single value for the upper limit of the therapeutic level of lidocaine in serum is an oversimplification because it does not take into account individual differences in drug-protein binding or accumulation of active metabolites.
\end{abstract}

\author{
Dennis E. Drayer, Ph.D., Beverly Lorenzo, B.S., Steven Werns, M.D.,* \\ and Marcus M. Reidenberg, M.D. New York, N.Y. \\ Departments of Pharmacology and Medicine, Cornell University Medical College
}

Lidocaine is eliminated mainly by biotransformation to monoethylglycinexylidide (MEGX); a small amount is excreted unchanged in the urine

Supported in part by NIH grants AG01441, AGO3280, and RR47 and by a grant from Hoffmann-La Roche.

Received for publication Dec. 10, 1982; accepted Jan. 26, 1983.

Reprint requests to: Dennis Drayer, Ph.D., Comell University Medical College, 1300 York Ave., Department of Pharmacology, New York, NY 10021.

*Present address: Division of Cardiology, University of Michigan Medical School, Ann Arbor, MI 48109 (about $3 \%$ of a dose in man). The major pathway of elimination of MEGX is biotransformation to 2,6-xylidine and, to a much lesser extent, to glycinexylidide (GX). The major lidocaine urinary metabolites in man are conjugates of 4hydroxy-2,6-xylidine ( $73 \%$ of a dose) ${ }^{6}, 13,15$ Chemical structures of lidocaine and these metabolites are shown in Fig. 1. MEGX and GX have pharmacologic activity. MEGX has an antiarrhythmic potency of the same order as lidocaine in vitro in a guinea pig atrium model ${ }^{4}$ and 


\section{BIOTRANSFORMATION OF LIDOCAINE}

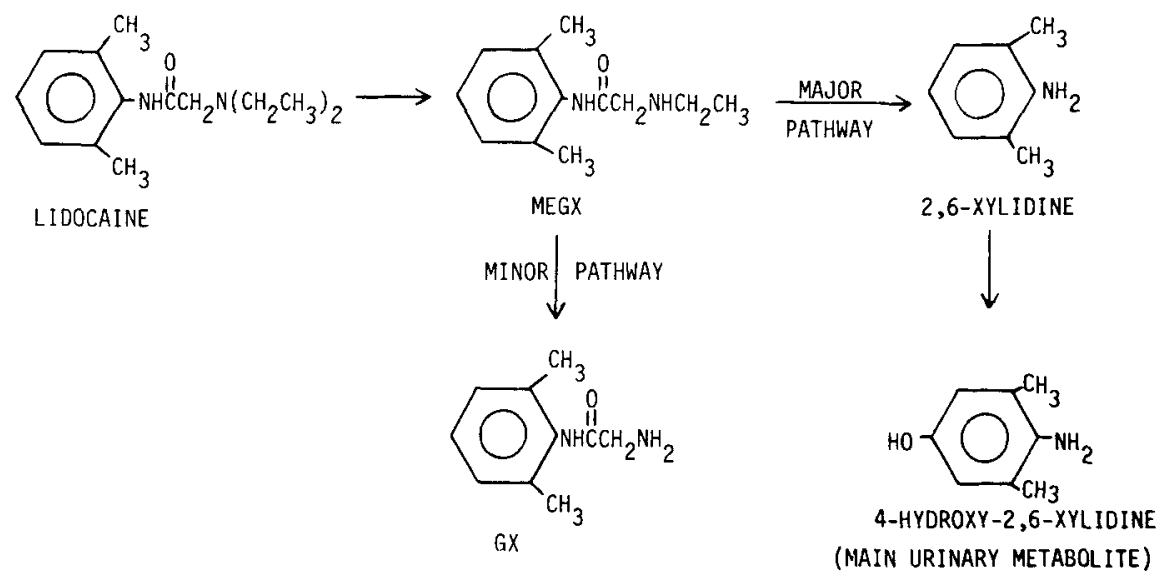

Fig. 1. Chemical structures for lidocaine and metabolites in man. Chemical structures for other metabolites (minor) are presented in Collinsworth et al. ${ }^{6}$

is about half as potent in vivo in dogs. ${ }^{22}$ MEGX also has local anesthetic activity ${ }^{6}$ and convulsant activity in animals. ${ }^{1,}{ }^{2}$ In fact, the convulsant activity of lidocaine and MEGX seem additive. ${ }^{2}$ Although the pharmacologic activity of MEGX in man has not been confirmed, the paresthesia and confusion in a patient of Halkin et al. ${ }^{12}$ on lidocaine were most likely due to MEGX, since the patient's lidocaine level of $3.5 \mu \mathrm{g} / \mathrm{ml}$ was within the accepted therapeutic range but the metabolite level of $4.2 \mu \mathrm{g} / \mathrm{ml}$ was higher than that of the parent drug.

In contrast, the antiarrhythmic activity of GX in mice was much less than that of lidocaine, ${ }^{24}$ and this was also seen in vitro in a guinea pig atrium model. ${ }^{4} \mathrm{GX}$ also seemed to potentiate the convulsant activity of MEGX and lidocaine in rats ${ }^{2}$ and itself had CNS depressant activity in these animals. When GX was infused into two normal subjects to achieve levels as high as, or higher than, those seen clinically after lidocaine, none of the major toxic effects associated with lidocaine therapy were observed. ${ }^{24} \mathrm{GX}$, however, did induce headache and adversely affected mental performance in these subjects. GX and MEGX also have the ability to constrict vascular smooth muscle. ${ }^{10}$

Our purpose is to provide serum level and elimination data for lidocaine, MEGX, and GX in cardiac patients of various ages. We also interpret the contribution of MEGX and GX to the pharmacologic activity of lidocaine after serum protein binding is taken into account.

\section{Materials and methods}

Our subjects were 33 patients in The New York Hospital Coronary Care Unit who were receiving lidocaine infusions at rates prescribed by their physicians for treatment of arrhythmias. For inclusion in the study, patients must have been receiving lidocaine for more than 24 $\mathrm{hr}$. Patients were assessed for manifestations of lidocaine toxicity, including muscle twitching, paresthesias, dysarthria, drowsiness, disorientation, and seizures at the time blood was drawn for assays. Blood was collected in a syringe and allowed to clot in a glass test tube. Contact with stoppers was avoided. The patients' charts were subsequently reviewed for diagnosis, concurrent drug therapy, clinical laboratory values, and clinical course. In each patient with manifestations of lidocaine toxicity the manifestations subsided after dosage reduction or withdrawal of lidocaine.

Six patients were considered to have lidocaine toxicity, and these were compared to the 27 who did not have toxicity. The following variables were considered: age; creatinine clear- 
Table I. Patient data and steady-state serum level data for $G X, M E G X$, and lidocaine in cardiac patients receiving lidocaine

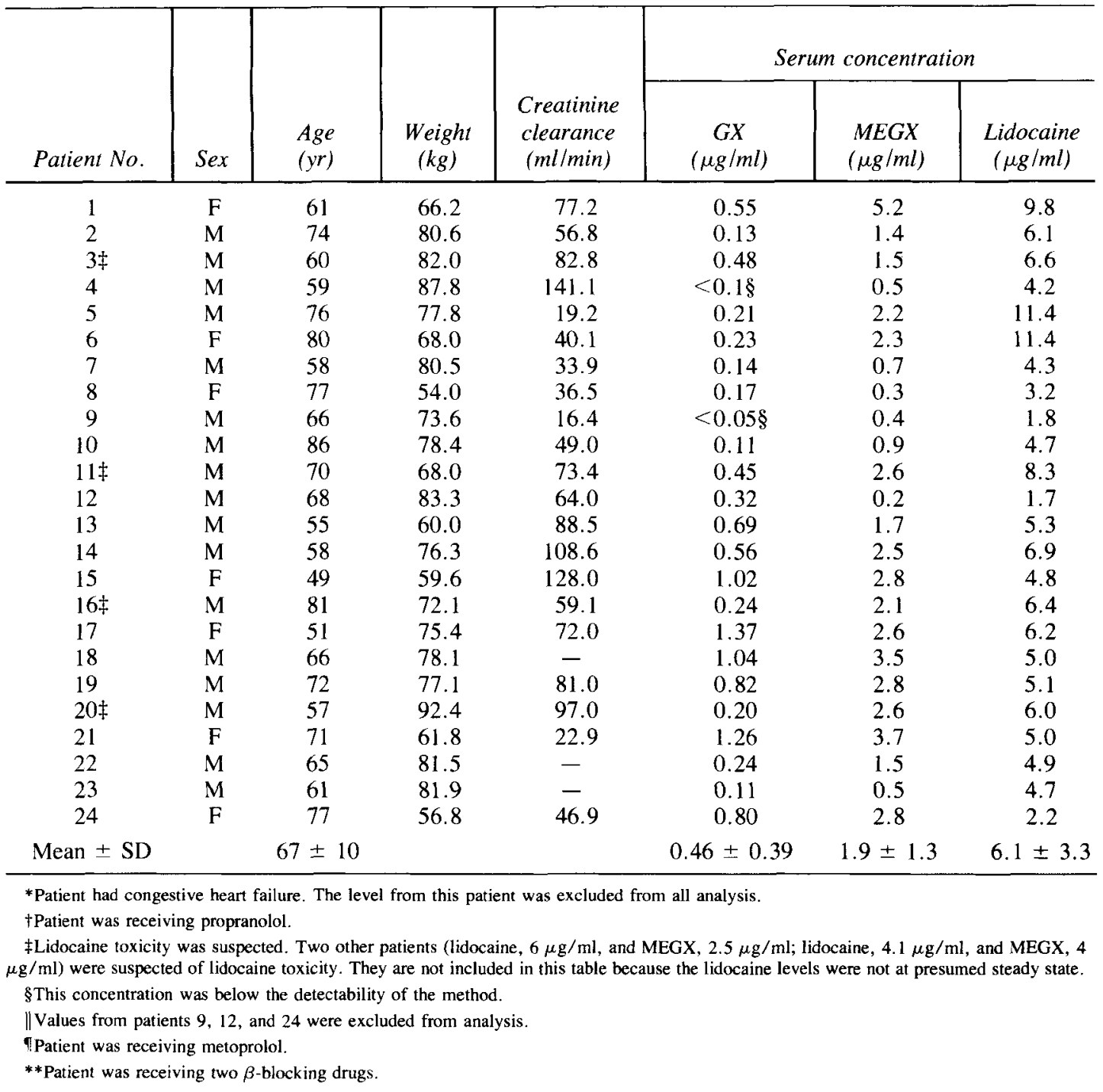

ance; serum bilirubin; SGOT; and serum lidocaine, MEGX, and GX levels. Of the 33 patients, 21 were presumed to be at steady state for lidocaine (infusion rate constant for the 12 $\mathrm{hr}$ before evaluation). Serum samples from these subjects were used for the kinetic studies (Table I). Most of these patients were also receiving propranolol or other $\beta$-adrenergicblocking drugs. Propranolol, and probably other $\beta$-adrenergic-blocking drugs as well, reduces lidocaine clearance. ${ }^{18}$ Most patients had a recent myocardial infarction. The results from three subjects with congestive heart failure are also presented in Table I, but they were not included in the analysis of the data because this disorder is known to decrease the clearance of lidocaine. ${ }^{26}$

Lidocaine, MEGX, and GX (supplied by Astra) were measured in serum or urine as follows: To a $16 \times 25 \mathrm{~mm}$ Teflon-capped glass extraction tube, add $1 \mathrm{ml}$ of serum or diluted urine, $100 \mu \mathrm{l}$ of a $20-\mu \mathrm{g} / \mathrm{ml}$ aqueous solution of the internal standard (the primary amine of etidocaine [also supplied by Astra]), $200 \mu \mathrm{l}$ of $5 \mathrm{~N} \mathrm{NaOH}$, and $200 \mu \mathrm{l}$ of a saturated $\mathrm{NaCl}$ so- 


\begin{tabular}{|c|c|c|c|c|}
\hline $\begin{array}{l}\text { Lidocaine } \\
\text { clearance } \\
(\mathrm{ml} / \mathrm{min} / \mathrm{kg})\end{array}$ & $\begin{array}{c}\text { Serum }[G X] \\
(\mu g / \mathrm{ml})\end{array}$ & $\begin{array}{c}\begin{array}{c}\text { Serum }[M E G X] \\
(\mu g / \mathrm{ml})\end{array} \\
\text { Lidocaine } \\
\text { infusion rate } \\
(\mathrm{mg} / \mathrm{kg} / \mathrm{min})\end{array}$ & $\begin{array}{c}\text { Serum } \\
\text { bilirubin } \\
\text { (mg/dl) }\end{array}$ & $\begin{array}{c}S G O T \\
\text { (units/l) }\end{array}$ \\
\hline $4.6^{*}$ & 12.2 & 115.1 & 0.4 & 57 \\
\hline $4.0^{\dagger}$ & 5.2 & 56.4 & 0.3 & 76 \\
\hline $7.4 \dagger$ & 10.0 & 31.2 & 1.1 & 20 \\
\hline 5.4 & - & 19.5 & 0.9 & 52 \\
\hline $3.4^{*}$ & 5.4 & 56.9 & 1.3 & 47 \\
\hline 2.6 & 7.9 & 77.5 & 0.6 & 16 \\
\hline 8.6 & 3.8 & 18.3 & 0.3 & 20 \\
\hline 5.9 & 8.9 & 15.7 & 0.3 & 25 \\
\hline $15.0 \dagger, \|$ & - & 13.3 & 2.3 & 126 \\
\hline 5.4 & 4.2 & 35.0 & - & 29 \\
\hline 5.3 & 10.2 & 58.8 & 3.0 & 42 \\
\hline $14.0 \dagger, \|$ & 13.3 & 10.0 & 1.0 & 111 \\
\hline $6.3 \dagger$ & 20.9 & 50.6 & - & - \\
\hline $5.7 \dagger$ & 14.4 & 63.8 & - & 83 \\
\hline $7.0 \dagger$ & 30.0 & 83.5 & 0.2 & 16 \\
\hline $6.5 \%$ & 5.7 & 50.0 & 0.4 & 34 \\
\hline $4.3 \dagger$ & 50.7 & 97.7 & 0.4 & 33 \\
\hline 5.1 & 40.0 & 135.7 & 0.4 & 7 \\
\hline 5.19 & 31.5 & 107.3 & 0.3 & 20 \\
\hline $7.2^{* *}$ & 4.7 & 59.7 & 0.4 & - \\
\hline $6.5^{*}, \dagger$ & 39.4 & 115.9 & 0.7 & 32 \\
\hline 5.0 & 9.6 & 58.4 & 0.4 & 30 \\
\hline 7.8 & 3.0 & 13.7 & 0.2 & 23 \\
\hline $16.0 \|$ & 22.9 & 80.0 & 0.5 & 10 \\
\hline $5.8 \pm 1.5$ & & & & \\
\hline
\end{tabular}

lution. Mix by vortexing briefly. Add $3 \mathrm{ml}$ amyl acetate, cap, and rotate on a mechanical rotator (Model 151; Scientific Industries) at approximately $14 \mathrm{rpm}$ for $30 \mathrm{~min}$. Centrifuge (4000 $\mathrm{rpm}, 5 \mathrm{~min}$ ) and transfer the organic phase to a new Concentratube (Laboratory Research). While vortexing, add $100 \mu \mathrm{l}$ of $0.1 \mathrm{~N} \mathrm{H}_{2} \mathrm{SO}_{4}$; continue vortexing vigorously for $30 \mathrm{sec}$. Centrifuge and inject $10 \mu \mathrm{l}$ of the acid phase into the liquid chromatograph.

We used a Waters HPLC equipped with a Model M6000A solvent delivery system, a U-6K injector, a reverse-phase column (micro-Bondapak/Phenyl, Waters), a Model 450 variable-wavelength $U V$ detector (Waters) set at $200 \mathrm{~nm}$, and a Varian A25 chart recorder. The mobile phase was Burdick and Jackson acetonitrile in phosphoric acid $(0.5 \mathrm{ml}$ in $1 \mathrm{l}$ water, which is then adjusted to $\mathrm{pH} 2.8$ with
$50 \%[\mathrm{w} / \mathrm{w}] \mathrm{NaOH})$ as a $10: 90$ mixture by volume. At the end of each workday, the system is flushed by pumping $20 \%$ acetonitrile in water at a flow rate of $2 \mathrm{ml} / \mathrm{min}$ for $20 \mathrm{~min}$. We have used this system for 6 mo with no problems. At a flow rate of $2 \mathrm{ml} / \mathrm{min}$, the retention times for GX, MEGX, the internal standard, and lidocaine are 5.8, 7.8, 9.5, and $11.5 \mathrm{~min}$, respectively. A linear relationship between peak height ratios (peak height of compound to peak of the internal standard) and concentration was as follows: 0.1 to at least $4 \mu \mathrm{g} / \mathrm{ml}$ for $\mathrm{GX}, 0.25$ to at least $8 \mu \mathrm{g} / \mathrm{ml}$ for MEGX, and $0.5 \mu \mathrm{g} / \mathrm{ml}$ to at least $16 \mu \mathrm{g} / \mathrm{ml}$ for lidocaine. A standard curve for GX, MEGX, and lidocaine from either serum or water was always determined concurrently with patient samples.

The coefficient of variation (CV) of the assay for GX, MEGX, and lidocaine, obtained from 
Table II. Serum level data for 33 cardiac patients receiving lidocaine, stratified by presence or absence of toxicity

\begin{tabular}{|c|c|c|c|c|c|}
\hline \multirow[b]{2}{*}{ Type } & \multirow{2}{*}{$\begin{array}{l}\text { No. of } \\
\text { patients }\end{array}$} & \multirow{2}{*}{$\begin{array}{l}\text { Age } \\
(y r)\end{array}$} & \multicolumn{3}{|c|}{ Concentration $(\mu \mathrm{g} / \mathrm{ml})$} \\
\hline & & & Lidocaine & $M E G X$ & $G X$ \\
\hline Nontoxic & 27 & $\begin{array}{c}67 \pm 10^{*} \\
(51-86) \ddagger\end{array}$ & $\begin{array}{l}6.0 \pm 3.3 \dagger \\
(2.2-16.5)\end{array}$ & $\begin{array}{l}1.9 \pm 1.3 \| \\
(0.3-5.2)\end{array}$ & $\begin{array}{c}0.45 \pm 0.44 \\
(0.05-1.4)\end{array}$ \\
\hline Toxic & 6 & $\begin{array}{c}68 \pm 10 \\
(57-81)\end{array}$ & $\begin{array}{l}6.2 \pm 1.3 \S \\
(4.1-8.3)\end{array}$ & $\begin{array}{l}2.6 \pm 0.8 \| \\
(1.5-4.0)\end{array}$ & $\begin{array}{c}0.46 \pm 0.33 \\
(0.20-1.1)\end{array}$ \\
\hline
\end{tabular}

*Mean $\pm \mathrm{SD}$

†Six subjects had lidocaine levels greater than $8 \mu \mathrm{g} / \mathrm{ml}$ without toxicity

$\Varangle$ Range.

\$Five subjects had lidocaine levels below $8 \mu \mathrm{g} / \mathrm{ml}$ with toxicity.

$\| \mathrm{P}<0.05$ by Wilcoxon's rank order test (one-tailed) compared to nontoxic levels

analysis of six replicate samples from a serum pool containinq $0.5 \mu \mathrm{g} / \mathrm{ml} \mathrm{GX,} 1 \mu \mathrm{g} / \mathrm{ml}$ MEGX, and $2.0 \mu \mathrm{g} / \mathrm{ml}$ lidocaine, was $4 \%, 2 \%$, and $2 \%$. The $\mathrm{CV}$ of this method, obtained from daily analysis $(\mathrm{N}=8)$ over 4 mo, was $7 \%$ for $\mathrm{GX}, 7 \%$ for MEGX, and $7 \%$ for lidocaine for our low standard containing $0.25 \mu \mathrm{g} / \mathrm{ml} \mathrm{GX}$, $0.5 \mu \mathrm{g} / \mathrm{ml}$ MEGX, and $1 \mu \mathrm{g} / \mathrm{ml}$ lidocaine.

The ratio of GX, MEGX, and lidocaine clearance to endogenous creatinine clearance was calculated from a single voided urine specimen and a simultaneously drawn blood sample. The ratio equals drug concentration in urine times serum creatinine concentration divided by the product of urine creatinine concentration and drug concentration in serum. Serum creatinine was measured by Auto-Analyzer and urine creatinine by the traditional alkaline picrate method with spectrophotometry. Lidocaine clearance $(\mathrm{ml} / \mathrm{min} / \mathrm{kg})$ was calculated for each patient as follows: Lidocaine clearance $=\mathrm{Li}$ docaine infusion rate/lidocaine serum level at presumed steady state. Creatinine clearance for each male subject was calculated from the following equation ${ }^{5}$ :

$$
\frac{[140-\text { age }(\mathrm{yr})] \times \text { weight in } \mathrm{kg}}{72 \times \text { serum creatinine }(\mathrm{mg} / \mathrm{dl})}
$$

For women, this ratio is multiplied by 0.85 .

The binding of lidocaine, MEGX, and GX was determined in serum drawn from five normal subjects and from seven patients 2 days after myocardial infarction. The blood was drawn into glass syringes and allowed to clot in $15-\mathrm{ml}$ glass test tubes. Serum from the normal subjects was used immediately, whereas that from most of the patients was stored in a frozen state before being used. Aliquots of serum were placed in dialysis tubing (Fisher Scientific). The dialysis tubing was then placed for $24 \mathrm{hr}$ in $\mathrm{pH}$ 7.4 phosphate buffer $(0.05 \mathrm{M})$ at room temperature containing either $0.5 \mu \mathrm{g} / \mathrm{ml} \mathrm{GX}, 2 \mu \mathrm{g} / \mathrm{ml}$ MEGX, or $2 \mu \mathrm{g} / \mathrm{ml}$ lidocaine. The samples were then analyzed by HPLC, and the ratio of the drug concentration in buffer to the concentration in dialyzed serum was considered the unbound fraction.

GX, MEGX, and lidocaine were added to heparinized whole blood from three subjects to give concentrations of $0.5,1$, and $2 \mu \mathrm{g} / \mathrm{ml}$. Half of each subject's blood was added to redstoppered Vacutainers (Becton, Dickenson). These tubes were inverted 10 times, left on their side at room temperature for $30 \mathrm{~min}$, and stored on their side in the refrigerator overnight. The other half of each subject's blood was placed in glass tubes and immediately stored upright in the refrigerator. The samples were then analyzed and compared.

Aliquots of standards containing $20 \mu \mathrm{g} / \mathrm{ml}$ GX, $20 \mu \mathrm{g} / \mathrm{ml}$ MEGX, and $20 \mu \mathrm{g} / \mathrm{ml}$ lidocaine in $\mathrm{pH} 7.4$ phosphate buffer $(0.05 \mathrm{M})$ were vortexed with equal volumes of 1-octanol. An aliquot of the original aqueous solution and an aliquot of the buffer after the octanol mixing were then analyzed by HPLC. The partition coefficient equals the concentration in 1-octanol divided by the concentration in buffer. The concentration of the compound in the organic phase is equal to the difference in concentration of the 


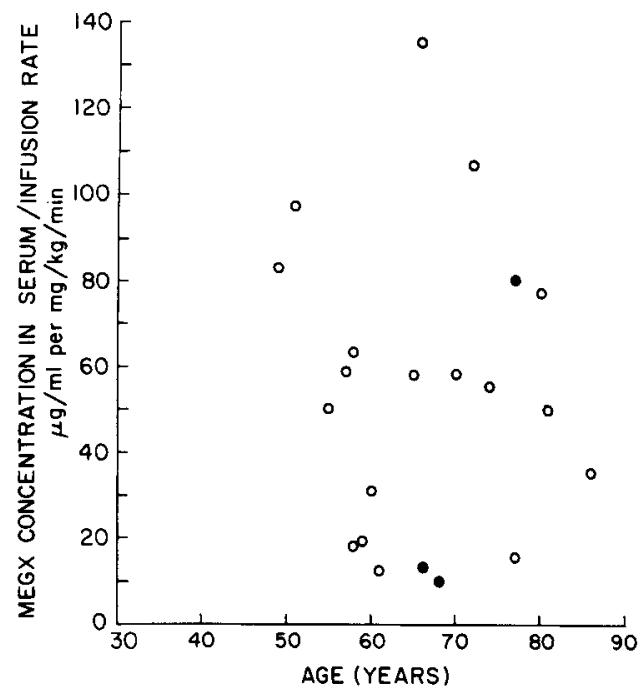

Fig. 2. Effect of age on steady-state MEGX serum levels normalized for lidocaine infusion rate. Solid circles are MEGX levels from the three outliers in Fig. 4.

compound in the aqueous buffer before and after 1-octanol extraction.

The linear regression equation was calculated by the least-squares technique. The $t$ test to show significant deviation of the correlation coefficient from zero was by the method of Swinscow. ${ }^{25}$

\section{Results}

The serum level data for lidocaine, MEGX, and GX in 27 nontoxic patients and six toxic patients are listed in Table II. The serum MEGX/lidocaine and GX/lidocaine ratios averaged $0.36 \pm 0.26$ and $0.11 \pm 0.11$. Twentyfour of these patients were presumed to be at steady state for lidocaine levels. Patient information, steady-state levels of lidocaine, MEGX, and GX, and lidocaine clearance values in these patients are presented in Table $\mathrm{I}$. The ages of the patients averaged $67 \pm 10 \mathrm{yr}$ (range, 49 to 86). In these patients at presumed steady state, MEGX serum levels averaged $31 \%$ that of lidocaine, whereas GX levels were much lower, averaging only $7.5 \%$ that of the parent drug.

Age had no effect on the presumed steadystate serum MEGX levels normalized for lidocaine infusion rate (Fig. 2) or normalized for lidocaine serum level. Serum MEGX $(\mu \mathrm{g} / \mathrm{ml}) /$

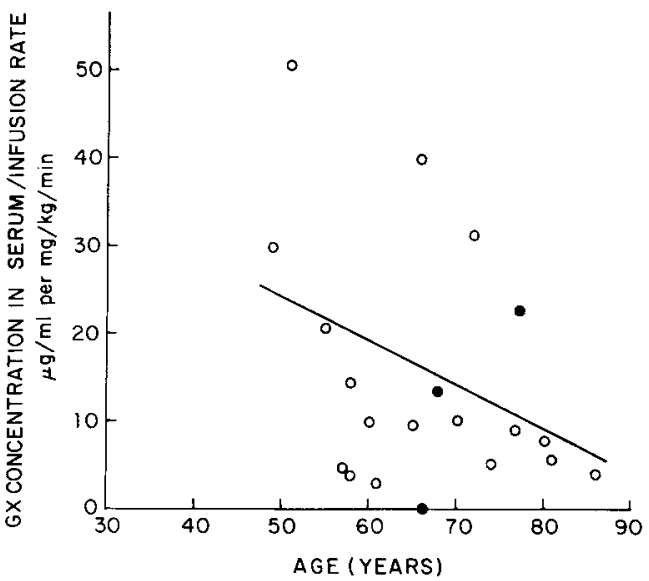

Fig. 3. Effect of age on steady state GX serum levels normalized for lidocaine infusion rate. Solid circles are GX levels from the three outliers in Fig. 4.

lidocaine infusion rate $(\mathrm{mg} / \mathrm{kg} / \mathrm{min})=65.4-$ 0.17 per year of age $(r=-0.05, \mathrm{~N}=21)$. The steady-state serum GX concentration normalized for lidocaine infusion rate declined with age (Fig. 3). Serum GX $(\mu \mathrm{g} / \mathrm{ml}) /$ lidocaine infusion rate $(\mathrm{mg} / \mathrm{kg} / \mathrm{min})=48.13-0.49 \mathrm{per}$ year of age, but this correlation is not strong $(\mathrm{r}=-0.39, \mathrm{P} 0.1, \mathrm{~N}=19)$. The correlation with age is even weaker when serum GX levels are normalized for lidocaine serum levels $(r=-0.17)$.

We have observed that in 6 of 27 subjects without toxicity, lidocaine levels were above 8 $\mu \mathrm{g} / \mathrm{ml}$. In one of these patients the lidocaine level was $16.5 \mu \mathrm{g} / \mathrm{ml}$ (MEGX, $0.77 \mu \mathrm{g} / \mathrm{ml}$, and GX, less than $0.1 \mu \mathrm{g} / \mathrm{ml}$ ) in serum from blood drawn $0.5 \mathrm{hr}$ after the end of a $34-\mathrm{hr}$ lidocaine infusion. In five of the six subjects with toxicity, lidocaine levels were below 8 $\mu \mathrm{g} / \mathrm{ml}$. In fact, the only difference between the toxic and the nontoxic patients in this study (Table II) was that on the average the toxic patients had higher MEGX levels. In the two groups, age, renal function (as determined by creatinine clearances), and liver function (as determined by serum bilirubin and SGOT) did not differ substantially.

The effect of age on lidocaine clearance is presented in Fig. 4. The lidocaine clearance averaged $5.8 \pm 1.5(\mathrm{SD}) \mathrm{ml} / \mathrm{min} / \mathrm{kg}$ and declined with age if the three very high lidocaine 


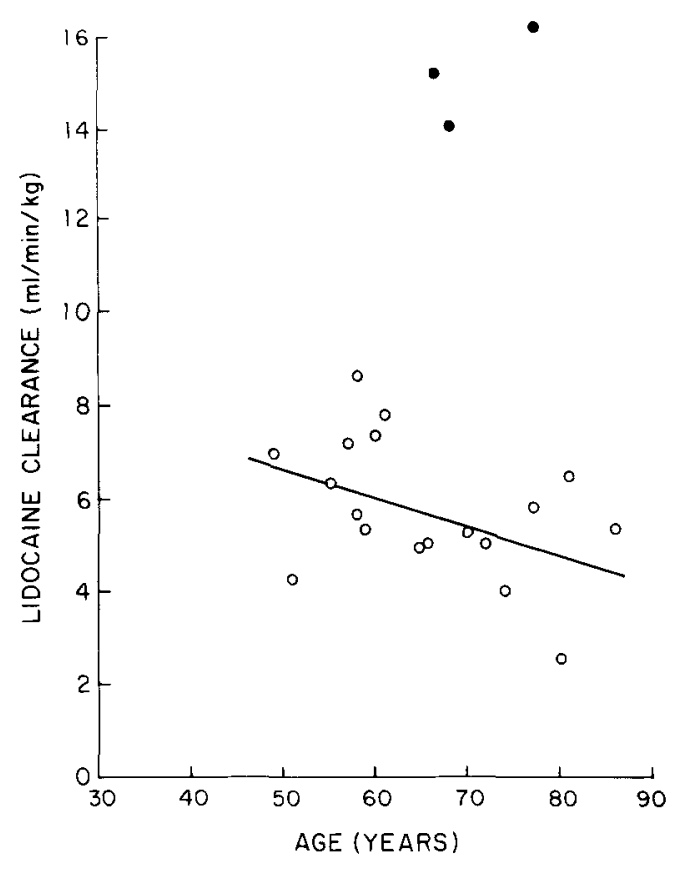

Fig. 4. Effect of age on lidocaine clearance. Three outliers (solid circles) were excluded from analysis.

values from patients 9,12 , and 24 are excluded. (These patients clearly represent a different patient population, since their values were more than 3 SD above the mean.) The equation of the best fit line by least-squares linear regression is as follows: Lidocaine clearance $(\mathrm{ml} / \mathrm{min} / \mathrm{kg})=$ $9.7-0.06$ per year of age $(r=-0.42$, $\mathrm{P}<0.05, \mathrm{~N}=18$ ). This clearance was, however, independent of creatinine clearance in 15 of the 18 subjects (in the other three, serum creatinine levels and therefore creatinine clearances could not be determined because of hemolysis). The ratio of GX renal clearance to creatinine clearance averaged $0.60 \pm 0.41$ (range, 0.14 to 1.7 ). In only 4 of the 22 subjects was this ratio above 1.0. The ratio of MEGX renal clearance to creatinine clearance averaged $0.72 \pm 0.48$ (range, 0.08 to 2.19 ). In only 4 of the 22 subjects was this ratio above 1.0 . The ratio of lidocaine renal clearance to creatinine clearance averaged $0.23 \pm 0.27$ (range, 0.02 to 1.17$)$. In only 1 of the 20 patients was this ratio above 1.0 . The lidocaine renal clearance averaged $3.2 \pm 1.8 \%$ of the total clearance $(\mathrm{N}=19)$.
The protein binding of lidocaine, MEGX, and GX in serum (at room temperature) from five normal subjects averaged $50 \pm 9 \%$ (mean $\pm \mathrm{SD}$ ), $15 \pm 3 \%$, and $5 \pm 4 \%$. The binding of lidocaine and MEGX to serum proteins drawn from seven patients 2 days after their myocardial infarctions averaged $55 \pm 6 \%$ and $14 \pm 3.0 \%$. Thus percent unbound in patients' serum water was $45 \%$ for lidocaine and $86 \%$ for MEGX. Since GX binding was only $5 \%$ and its total level was so low, it was considered inconsequential and was not studied further.

Heparinized blood stored in red-stoppered Vacutainers had no effect on GX and MEGX plasma concentration levels, but exposure of lidocaine to the stopper lowered the lidocaine concentration level in plasma by $20 \%$.

The octanol/buffer ( $\mathrm{pH}=7.4$ ) partition coefficient $\left(\mathrm{K}_{\mathrm{p}}\right)$ was 65.0 for lidocaine, 5.7 for MEGX, and 1.3 for GX.

\section{Discussion}

The individual ratios of serum levels of MEGX to lidocaine and of GX to lidocaine in the 33 cardiac patients averaged $0.36 \pm 0.26$ and $0.11 \pm 0.11$. These ratios are of the same order as those in the literature. ${ }^{7,12,16}$ The intensity of a drug's action is related to its concentration in plasma water, since this establishes the diffusion gradient for the drug to get to the receptor site. The correction factor for converting the total MEGX/lidocaine ratio in serum to that in serum water equals $86 \% / 45 \%$, or 1.9 (protein-binding data from seven patients with a myocardial infarction 2 days before analysis), and therefore the MEGX/lidocaine ratio in serum water averages $0.68 \pm 0.49$. In fact, MEGX levels in serum water were at least $80 \%$ or more than those of lidocaine in 11 of the 33 patients. Assuming that MEGX is 0.5 to 1 times as potent as lidocaine for antiarrythmic and toxic effects (since this was the potency observed in animals), then MEGX contributes to the pharmacologic activity of lidocaine therapy in a substantial proportion of lidocaine-treated patients.

The protein binding of lidocaine is known to be increased in several clinical situations, such as recent myocardial infarction ${ }^{19}, 21$ (applies to most of our patients), increasing age, chronic 
renal failure, epilepsy (treated), malignancy (reviewed in Routledge et al. ${ }^{20}$ ), and trauma. ${ }^{9}$ The increased lidocaine protein-binding is thought to be due to the rise of $\alpha_{1}$-acid glycoprotein in plasma, which can increase for 5 to 7 days after these events and can remain elevated for as long as 2 to $3 \mathrm{wk}^{9,}{ }^{914}$ This implies that the ratio of MEGX to lidocaine in plasma water may be above 0.68 if the patient receiving the lidocaine has a marked increase in levels of this binding protein after myocardial infarction.

Because of the low plasma levels of GX relative to lidocaine, even after correction for protein-binding differences and the low potency of GX in experimental studies relative to lidocaine, we believe that GX contributes very little to the pharmacologic effects of lidocaine.

There is no effect of age on the steady-state MEGX plasma level normalized for lidocaine infusion rate (Fig. 2). This conclusion is also reached if one plots the data of Halkin et al., ${ }^{12}$ but the steady-state GX plasma level normalized for lidocaine dose decreases with age (Fig. 3). This was unexpected, since GX is eliminated $50 \%$ unchanged in the urine, ${ }^{24}$ and renal function, as measured by endogenous creatinine clearance, decreases in elderly persons. ${ }^{8}$ This decrease in normalized GX plasma levels in elderly persons may be explained by proposing that GX formation from MEGX is decreased in elderly persons to a greater extent than aging slows the elimination of GX into urine.

Davison et al. ${ }^{7}$ reported that in only 88 of 362 blood samples drawn from patients with suspected lidocaine toxicity was the lidocaine level above $5 \mu \mathrm{g} / \mathrm{ml}$. The remainder of patients apparently had lidocaine levels below this value. Some of the toxic patients had elevated MEGX levels. Lidocaine levels in nontoxic patients were not measured. Buckman et al. ${ }^{3}$ report that 20 of 44 patients who had lidocaine levels below $6 \mu \mathrm{g} / \mathrm{ml}$ had toxicity, and all six patients with higher lidocaine levels had toxicity. Lidocaine plasma levels associated with serious toxicity have also been reported to be above $8 \mu \mathrm{g} / \mathrm{ml} .^{11}$ Of our 27 subjects without toxicity, six had serum lidocaine concentrations above $8 \mu \mathrm{g} / \mathrm{ml}$. We also observed that five of six subjects with toxicity had lidocaine levels below $8 \mu \mathrm{g} / \mathrm{ml}$. In fact, the only difference we observed between the toxic and nontoxic patients in our study (Table II) was that, on the average, the toxic patients had higher MEGX levels. The implication is that MEGX contributes to toxicity during lidocaine therapy. We therefore suggest that the concept of a single value for the upper limit of the therapeutic range for serum lidocaine concentration is an oversimplification because it does not take into account individual difference in protein binding of the parent drug or active metabolite accumulation.

Three elderly subjects (ages above $65 \mathrm{yr}$ ) had very rapid lidocaine clearance values and clearly represented a different patient population from the remainder of the elderly subjects. Review of the charts of these patients gave no reason for their high clearance values. In a much smaller study, Nation et al. ${ }^{17}$ observed one elderly subject who had a lidocaine clearance value that was more than $2 \mathrm{SD}$ above the mean of the values of the other elderly subjects.

The ratio of lidocaine, MEGX, and GX renal clearance to creatinine clearance is below 1.0 for most of our patients, indicating that net renal tubular secretion of these compounds does not occur. However, the high lipid solubility of lidocaine and MEGX $\left(\mathrm{K}_{\mathrm{p}}\right.$ substantially above $1.0)$, and to a lesser extent of $\mathrm{GX}\left(\mathrm{K}_{\mathrm{p}}=1.3\right)$, permits diffusion of these compounds from the urine in the renal tubules back into the blood. This may mask any renal tubular secretion of these basic compounds into the urine.

Lidocaine is more lipophilic (highest $K_{p}$ ) than its two metabolites, MEGX and GX, and is $50 \%$ bound to plasma proteins in normal subjects. GX is the least lipophilic (lowest $\mathrm{K}_{\mathrm{p}}$ ) of these three compounds and is only $5 \%$ bound to plasma proteins. MEGX is of intermediate polarity and protein binding.

Several years ago Stargel et al ${ }^{23}$ reported that collecting blood in red-stoppered Vacutainer tubes caused about a $28 \%$ reduction in lidocaine serum levels. We confirmed this; it still is a problem. It has been proposed that the chemical tris(2-butoxyethyl)phosphate, which is present in the rubber stopper, is leached out and displaces this basic drug from its serum protein binding sites. The drug then redistributes into the erythrocytes, producing spuriously low 
serum levels. Collecting blood in red-stoppered Vacutainers had no effect on serum levels of MEGX and GX. This observation is compatible with the above concept, since MEGX and GX are only slightly bound to serum proteins.

\section{References}

1. Atkinson AJ, Stec GP, Lertora JJ, Ruo TI, Thenot JP: Impact of active metabolites on monitoring plasma concentrations of therapeutic drugs. Ther Drug Monit 2:19-27, 1980.

2. Blumer J, Strong JM, Atkinson AJ: The convulsant potency of lidocaine and its $N$-dealkylated metabolites. J Pharmacol Exp Ther 186:31-36, 1973.

3. Buckman K, Claiborne K, de Guzman M, Walberg CB, Haywood LJ: Lidocaine efficacy and toxicity assessed by a new rapid method. CLIN Pharmacol Ther 28: 177-181, 1980.

4. Burney RG, Di Fazio CA, Peach MJ, Petrie KA, Silvester MJ: Anti-arrhythmic effects of lidocaine metabolites. Am Heart J 88:765-769, 1974.

5. Cockcroft DW, Gault MH: Prediction of creatinine clearance from serum creatinine. Nephron 16:31-41, 1976.

6. Collinsworth KA, Kalman SM, Harrison DC: Clinical pharmacology of lidocaine as an antiarrhythmic drug. Circulation 50: 1217-1230, 1974.

7. Davison R, Parker M, Atkinson AJ: Excessive serum lidocaine levels during maintenance infusions: Mechanisms and prevention. Am Heart J 104: 203-208, 1982.

8. Drayer DE, Romankiewicz J, Lorenzo B, Reidenberg MM: Age and the renal clearance of cimetidine. Clin Pharmacol Ther 31:45-50, 1982.

9. Edwards DJ, Lalka D, Cerra F, Slaughter RL: Alpha $_{1}$-acid glycoprotein concentration and protein binding in trauma. Clin Pharmacol Ther 31:62-66, 1982.

10. Fukuda S, Takeshita H, Toda N: Modifications by lidocaine and its $\mathrm{N}$-dealkylated metabolites of the response of the isolated rabbit aorta to transmural electrical stimulation. Anesthesiology 53: 106-112, 1980.

11. Gianelly R, Von der Groeben JO, Spivack AP, Harrison DC: Effect of lidocaine on ventricular arrhythmia in patients with coronary heart disease. N Engl J Med 277:1215-1219, 1967.

12. Halkin H, Meffin P, Melmon KL, Rowland M: Influence of congestive heart failure on blood levels of lidocaine and its active monodeethy- lated metabolite. Clin Pharmacol Ther 17: 669-676, 1975.

13. Hollunger $\mathbf{G}$ : On the metabolism of lidocaine. II. The biotransformation of lidocaine. Acta Pharmacol Toxicol 17:365-373, 1960.

14. Johansson BG, Kindmark CO, Trell EY, Wollheim FA: Sequential changes of plasma proteins after myocardial infarction. Scand J Clin Lab Invest 29(Suppl 124): 117-126, 1972.

15. Keenaghan JB, Boyes RN: The tissue distribution, metabolism and excretion of lidocaine in rats, guinea pigs, dogs and man. J Pharmacol Exp Ther 180:454-463, 1972.

16. Narang PK, Crouthamel WG, Carliner NH, Fisher ML: Lidocaine and its active metabolites. Clin Pharmacol Ther 24:654-662, 1978.

17. Nation RL, Triggs EJ, Selig M: Lidocaine kinetics in cardiac patients and aged subjects. $\mathrm{Br} \mathbf{J}$ Clin Pharmacol 4:439-448, 1977.

18. Ochs HR, Carstens G, Greenblatt DJ: Reduction in lidocaine clearance during continuous infusion and by coadministration of propranolol. N Engl J Med 303:373-377, 1980.

19. Routledge PA, Shand DG, Barchowsky A, Wagner G, Stargel WW: Relationship between alpha $_{1}$-acid glycoprotein and lidocaine disposition in myocardial infarction. Clin Pharmacol. THER 30:154-157, 1981.

20. Routledge PA, Stargel WW, Barchowsky A, Wagner GS, Shand DG: Control of lidocaine therapy: New perspectives. Ther Drug Monit 4:265-270, 1982.

21. Routledge PA, Stargel WW, Wagner GS, Shand DG: Increased alpha-1-acid glycoprotein and lidocaine disposition in myocardial infarction. Ann Intern Med 93:701-704, 1980.

22. Smith ER, Duce BR: The acute antiarrhythmic and toxic effects in mice and dogs of 2-ethylamino- $2^{\prime} 6^{\prime}$-acetoxylidine (L-86), a metabolite of lidocaine. J Pharmacol Exp Ther 179:580. $585,1971$.

23. Stargel WW, Roe CR, Routledge RA, Shand DG: Importance of blood-collection tubes in plasma lidocaine determinations. Clin Chem 25:617-619, 1979.

24. Strong JM, Mayfield DE, Atkinson AJ, Burris BC, Raymon F, Webster LT: Pharmacological activity, metabolism and pharmacokinetics of glycinexylidide. Clin Pharmacol Ther 17: 184-194, 1975.

25. Swinscow TDV: Statistics at square one. London, 1978, British Medical Association, p 67.

26. Waller ES: Pharmacokinetic principals of lidocaine dosing in relation to disease state. $\mathrm{J}$ Clin Pharmacol 21:181-194, 1981. 